\title{
Recent Revisions of GNP Data
}

\author{
Keith M. Carlson
}

$\mathrm{N}$ December 1985, the U.S. Department of Commerce announced a major revision of the nation's income and product accounts.' This revision, which is done about every five years, was the eighth of its kind. The purpose of this comprehensive revision was to update the gross national product (GNP) accounts, reflecting any new information, new procedures, and changes in the economic structure.

The U.S. income and product accounts were created in the 1930 s, though they were not published on a regular basis until after Word War II." Their purpose is to provide a measure and understanding of the economic health of the nation. For a brief summary of national income accounting, see the shaded box on p. 18.)

This article discusses the nature and extent of the most recent revision, along with some background information to aid the nontechnical reader. "The aticle focuses on the effect of the revision on GNP, output

Keith $M$. Carlson is an assistant vice president at the Federal Reserve Bank of St. Louis. Sandra Graham and Thomas A. Pollmann provided research assistance.

A detailed discussion of the revision can be found in various articles in the Survey of Current Business. See U.S. Department of Commerce (1985b, 1985c).

2For a discussion of the historical development of the U.S. income and product accounts, see U.S. Department of Commerce (1985a). and prices. The effect of the revision on the interpetation of post-World War 11 economic fluctuations and on centain key historical felationships also receives consideration.

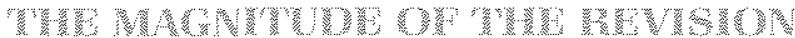

The shaded box on page 20 describes the major sources of the revision. Although GNP data for earlier years were diso affected somewhat, the revision primarily affected GNP data from 1970 to 1984.

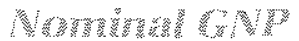

Table 1 summarizes the effect of the revision on nominal GNP for alternate years from 1948 to 1984 . The revision has increased the level of GNP in each year shown; the largest changes, however, have occured since 1970 . The revision had little impact on the annual growth rates of nominal GNP; it raised the growth rate from $1948-84$ from 7.6 to 7.7 percent.

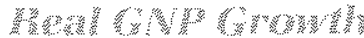

Nominal GNP revisions can be compared directly in terms of dollar amounts; constant-dollar, or real, GNP estimates cannot be as easily compared because the base period has been shifted. Consequently, to compare the effect of the revision on real GNP estimates, one must examine its impact on the growth rates of the old and revised real GNP estimates. 


\section{The Essentials of National Income and Product Accounting}

The national income and product accounts provide a statistieal summary of the economy, showing the volume, composition and uses of the national output. The total production of the nation is measured in wo ways in terms of products, that is, the value of goods and services, and in terms of the incomes generated in preduetion. The accompanying table summarizes the national income and product account for 1984.

The left side of the table, the income side of the account shows wages and salanies and other forms of income, indiect business taxes and capilal consumption allowances and other small items gen erated in the produetion process. The total of these items is labeled charges against gross national product." Because the two sides of the income and produet account are estimated independently, given imperfections in the souree data, they are net necessarily equal The error is called statistical discrepancy, it has no economic significancel
The right side of the table, the product side, is divided into the major markets for the econonys output: personal constimption, business investment government purchases and net exports. The sum of the expenditures is the gross national produet (GNP).

The table is only one of many in the accounts but it is the most fundamental one. Anong the most important of the remaining accounts are those that show the receipts and expenditures of the major eeonomic groups in the economy. The personal income and outlay account shows the ineome receipts and expenditures of persons. The govern ment receipts and expenditures account summarizes the actinties of federal, state and local governments. The foreign transactions account summarizes international transactions that im pinge on US income and product. Finally the gross saving and investment account cuts across economic groups, showing their saving and investment fransactions in summary form

National Income and Product Account, 1984 (bilitons of dollars)

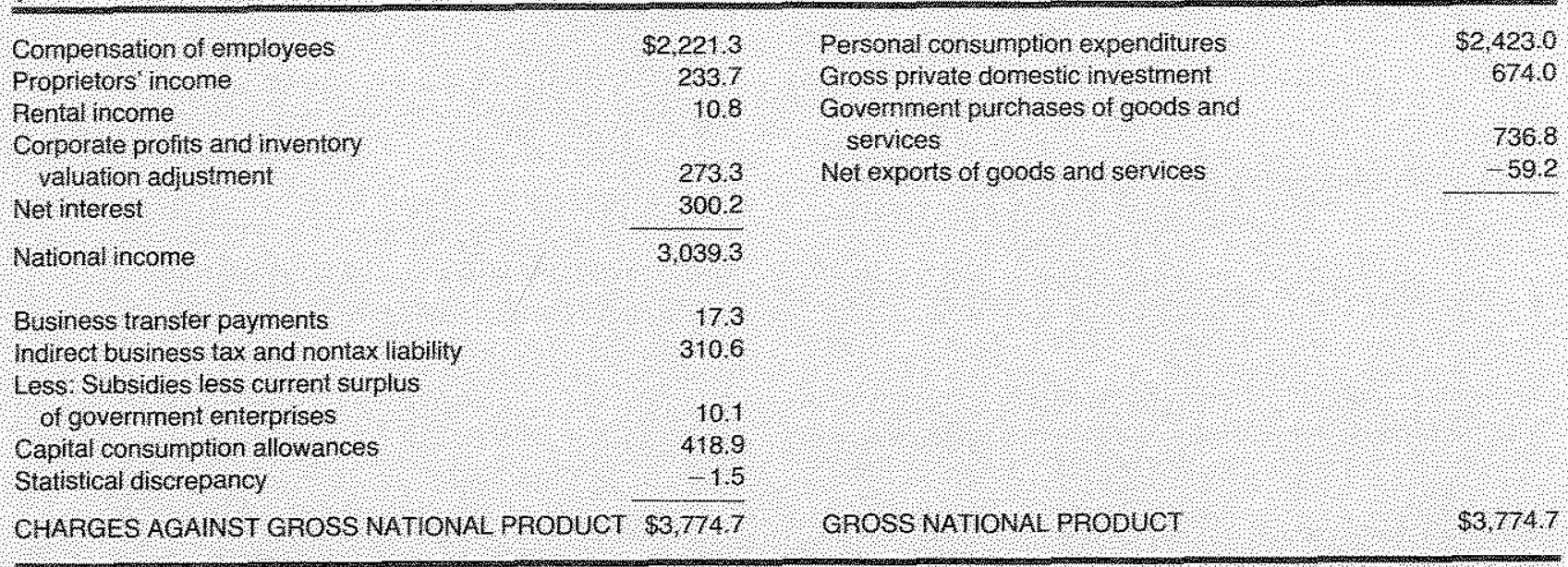

NOTE Numbers nay not add due to rounding. SOUREE Councl of Economio Advisers. 
Table 1

\section{A Comparison of Old and Revised Nominal GNP: 1948-84 (dollar amounts in billions)}

\begin{tabular}{|c|c|c|c|}
\hline & 90 & Revised & $\begin{array}{l}\text { percent } \\
\text { change }\end{array}$ \\
\hline 1948 & $\$ 259,5$ & $\$ 2616$ & $81 \%$ \\
\hline 1950 & 2865 & 2803 & 63 \\
\hline 1952 & 3480 & 3516 & 103 \\
\hline 1954 & 3668 & 3725 & 155 \\
\hline 1956 & 4217 & 4282 & 154 \\
\hline 1958 & 4497 & 4568 & 158 \\
\hline 1960 & 5065 & 5153 & 174 \\
\hline 1962 & 5650 & 5746 & 170 \\
\hline 1964 & 637 ? & 6498 & 190 \\
\hline 1966 & 7560 & 720 & 212 \\
\hline 1968 & 8734 & 8927 & 221 \\
\hline 1970 & 9927 & 10155 & 230 \\
\hline 1972 & 1185,9 & 12128 & 221 \\
\hline 1974 & 1,4342 & 14720 & 269 \\
\hline 1976 & 17180 & 17828 & 377 \\
\hline 1978 & 21609 & 22497 & 397 \\
\hline 1980 & 26317 & 27320 & 381 \\
\hline 1982 & 3,090 & 3,1660 & 3,5 \\
\hline 1984 & 36628 & 37747 & 300 \\
\hline
\end{tabular}

Table 2 summarizes, on a peak-to-peak basis, the growth of the old and revised estimates of real GNP from 1948 to 1985. The growth of real GNP was higher only for the earliest period, which includes the defense buildup for the Korean War. All other revised peak-to peak growth rates were lower; as a result, real GNP growth for the entire IV/1948-IIJ/1985 period was revised downward about 0.2 percent, from a $3.4 \mathrm{per}$ cent annual growth rate using the old estimates to a 3.2 percent rate with the revised data.

\section{6.}

Changes in the GNP deflator reflect changes in both prices and the composition of spending. Consequently, revision of the GNP accoums affects estimates of the deflator via several channels. Table 3 summarizes ates of change in the GNP deflator for peak-topeak periods from 1948 to 1985.

With only two exceptions, IV/1948-II/1953 and I/1980-II/1981, the change in the deflator was revised upward. In conjunction with the virtually identicalsized revisions in the growth of real GNP summarized in table 2 , if is clear that the revision primarily redis tributed a given change in nominal GNP from real output to higher prices. For the period as a whole, the
Table 2

The Growth of Real GNP: Old and Revised Series (compounded annual rates of change)

\begin{tabular}{|c|c|c|c|}
\hline Peak-to-Peak & Previous & Revised & $\begin{array}{l}\text { Direction of } \\
\text { revision }\end{array}$ \\
\hline W/1948-1/1953 & $5,3 \%$ & $5,7 \%$ & 1 \\
\hline $111953-1111957$ & 22 & 18 & 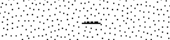 \\
\hline $11 / 1957>1 / 1960$ & 30 & 28 & 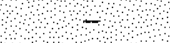 \\
\hline $1 / 1960-11 / 1969$ & 42 & 40 & त \\
\hline $11 / 1969-1 / 1973$ & 35 & 30 & 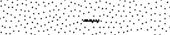 \\
\hline W/973 11980 & 27 & 25 & 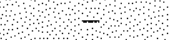 \\
\hline $111980+111981$ & 11 & 06 & 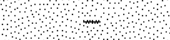 \\
\hline $11198141 / 1985$ & 26 & 24 & \\
\hline N/1948-11/1985? & 3.4 & 32 & \\
\hline \multicolumn{4}{|c|}{$\begin{array}{l}\text { Data calculated by he previous method are nol available after } \\
111985 \text {. }\end{array}$} \\
\hline
\end{tabular}

\section{Table 3}

Changes in the GNP Deflator: Old and Revised Series (compounded annual rates of change)

\begin{tabular}{|c|c|c|c|}
\hline Peak-10 Peak & Previous & Revised & $\begin{array}{l}\text { Direction of } \\
\text { revision }\end{array}$ \\
\hline $111948-1 / 1958$ & $2 \%$ & $19 \%$ & 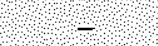 \\
\hline $11 / 1953-11 / 1957$ & 25 & 29 & 4 \\
\hline $11 / 1857$ 1/1960 & 19 & 23 & 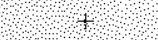 \\
\hline $11960-11 / 1969$ & 26 & 28 & 3 \\
\hline 1111969 य 11973 & 5.2 & 59 & 1 \\
\hline $1 / 1973-1 / 1980$ & 76 & 80 & 1 \\
\hline $11980-11 / 1981$ & 98 & 96 & 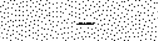 \\
\hline $111 / 1981>11 / 19853$ & 41 & 43 & 4 \\
\hline $111948 \quad 111985$ & 48 & 43 & . \\
\hline
\end{tabular}

Data alculated by ho prevpus method are not a watlable attet $11 / 985$

revised deflator increased at a 4.3 percent annual rate, up slightly from the previousty estimated 4.1 percent rate.

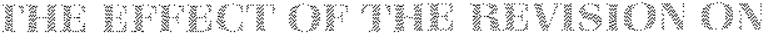

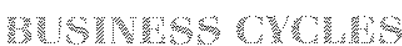

As pointed out above, the revision had only a minos effect on the growth of nominal GNP: the growth of real GNP was revised downward slighty and the in- 


\section{The Sources of National Income and Product Accounts Revision}

The Commerce Department avides the solnees of revision hinto lwo niajur calegeries. 41 de finitional

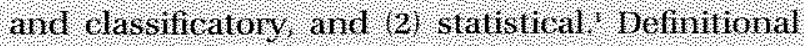
and classifieatony ehanges uphate the accounts to reflect he ohranging structure of the $\mathrm{S} S \mathrm{~s}$ economy staristical changes noomporate hevil avallable and revised source data, inproved estimating procer dures and a shift in the base period for edleulating

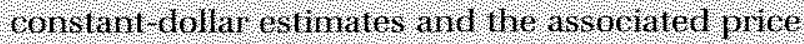
indexes.

\section{Definitional and Chssiffcatory changes}

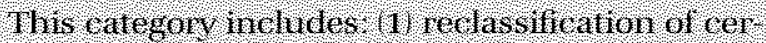
tain bisthess expendinues as investment. 2 . ehanged ligathent or feder al employ ment bernefli

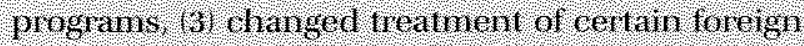

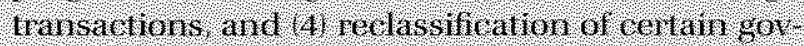

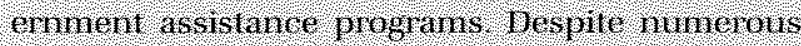
Gefinitional and classificatory ahanges, the revision

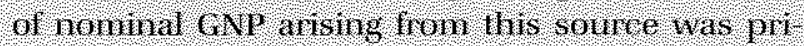

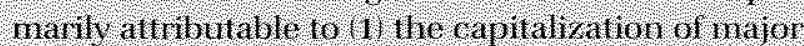

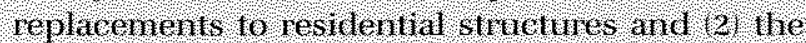

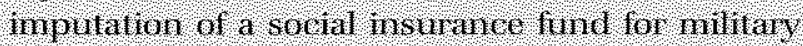
retrement. The net effect of ather dhanges on GWr was $11 \mathrm{~g} 11 \mathrm{~W}$ rogatwe?

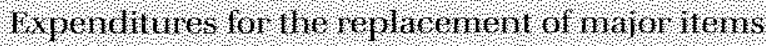
Wike a root or a liearing systemi in a house were reclassifled as invest ment in residenilal strul tures: Previensly such replarenents were harged ofl 10 gument expense, This change woreased nommal GNPbV 614,1 billion n 1984 .

The Defense 4 linomzation $4 \mathrm{ct}$ of fiscal $1984 \mathrm{es}$.

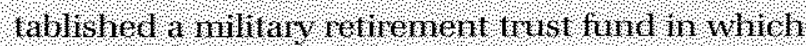
conthibutions by the govermment are equal to benefis paid. These expendinures are now healed as halional defense purehises, proviously, such benefis had ued induded in govemment lanster paymonts. This glange increased nommal GND in $10846 y>167101110 n$

A Iisting of hese changes is provided in US, Department of commerce $(19856,1985 \mathrm{c})$

\section{Statistical Changes}

These changes include lie shif of the base pe. riod from 1972 io 1982 , the ineorporation of hew and revised data from regularly used sounees avall able anmually or on a benchmank basis " he use of new source dala, and new estimation proed dires.

The stitistical dhanges with the largest impuet were as follows:

11. Improved adjustments for misrepolming on lax retums. Whough these adjustments are re.

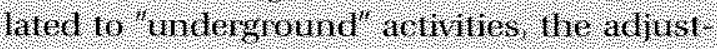
hrent iselt is nol a neaslite of he size of the undergrolund oconomy. These a diustments

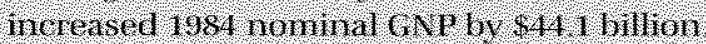

2) mproved nethorblogy and new dith for rest dentil mesment. Residential inesmient Was revised wphatd by s26. 2 billinn il 1984 ?

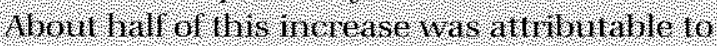

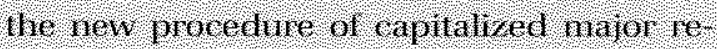

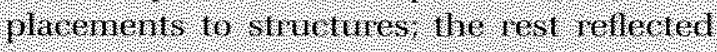
slunislugl ohanges dive to now dath

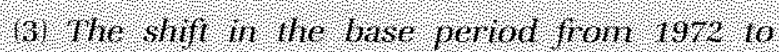
1982. This shift redweed he tate of real growih and for a given path of hominal GAr. inereased the rate of diange in Whe s NP defla tor See loox on apposite prage for an example.

4. Improved price inder for eomplarers. This

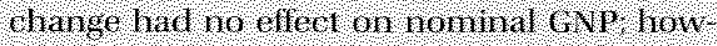
ever, it mproved estimates of real producers?

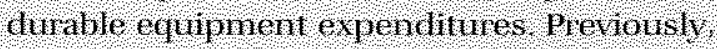
the Commerce beparthent had assumed

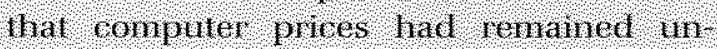
elanged the commeres 1 gepar ment now Ineorporales a 10 pere ent dechine por vear in compliter prices from 1970 to 1984 . Thes Change sabstantially incrgases estimates of real computer expenditures over the pertod.

For example GNP does not indtude llegal activites, for a de talled discussion of the underground ecanomy, see Carson (1984) and Paker (1984).

This leaves $\$ 14,9$ bilion of statistical changes affecting nominal GNP that are attibutable to other changes The Conmerce beparment did not allocate these renaining changes: 


\section{The Effect of Shifting the Base Period on Real GNP Growth}

The effect on real cNe of shifting to a more recent base period can be shown by using a simplified example in which there are ony two commodities, $A$ and $B$ Real GNP an be obtained by multiplying the guantifies of $A$ and $\mathrm{s}$ sold in ach year by theis prices in the base period for example, real GNP growth can be calculated as follows.

11 Using year 1 as base period.

\begin{tabular}{|c|c|c|c|c|c|}
\hline \multicolumn{2}{|c|}{ Price (dollars) } & \multicolumn{2}{|c|}{$\begin{array}{l}\text { Quantity } \\
\text { (number) }\end{array}$} & \multicolumn{2}{|c|}{ value (tollars) } \\
\hline Year 1 & Year 2 & Year 1 & Year 2 & Yearl: & Year 2 \\
\hline$\$ 5$ & $\$ 9$ & 10 & 11 & $\$ 50$ & $\$ 55$ \\
\hline 6 & 1 & 10 & 16 & 60 & 96 \\
\hline & & & & $\$ 110$ & $\$ 151$ \\
\hline & & $\$ 151$ & & & \\
\hline
\end{tabular}

crease of the GNP deflator was revised tupward slightly. Because these changes are due chicfly to the shift of the base period from 1972 to 1982 , they had no significant effect on the general movement of prices and real GNP over the post-World War ll period.

Table 4 summarizes real GNP growth over expansions and contractions on the old and the revised basis. An examination of the quaterly movements of real GNP around turning points reveals no changes in the timing of the business cycle. There were however, some changes in the severity of contractions and the strength of expansions.

The left side of table 4 reveals that real growth in all economic expansions was revised downward, except for the Korean War expansion of $1949-53$. Real growth during the 1970-73 and 1980-81 expansions was reduced most by the revisions; all revisions, however, were minor. Moreover, the ordering of the expansion periods from strongest to weakest was left unchanged by the revision.

The right side of table 4 summarizes the effect of the revision on the severity of recessions. The effect was
(2) Using year 2 as base period:

\begin{tabular}{|c|c|c|c|c|c|}
\hline \multicolumn{2}{|c|}{ Pilce (dollars) } & \multicolumn{2}{|c|}{$\begin{array}{l}\text { Quantity } \\
\text { (number) }\end{array}$} & \multicolumn{2}{|c|}{ Value (dollars) } \\
\hline Year 1 & Year 2 & Year 1 & Year 2 & Yearl & Year 2 \\
\hline$\$ 5$ & $\$ 9$ & 10 & 11 & $\$ 90$ & $\$ \$ 9$ \\
\hline 6 & 7 & 10 & 16 & 70 & 12 \\
\hline & & & & $\$ 160$ & $\$ 211$ \\
\hline \multicolumn{2}{|c|}{ Real GNP growt } & sc & $=$ & $319 \%$ & \\
\hline
\end{tabular}

In both wases, the growth rate of real GNP is a werghted average of growth rates of A and B In case 1 the weights are based on fhe prices in year 1, in case 2 , the weights are based on prices in year 2 The example reflects the assumption that the price of $A$ nises none than the price of $B$, while the quantily of A hereases less han B, As a result A receives mole weight when year 2 is used as hhe base penod than when year 1 is used

not as unifom as for expansions: recessionary declines in real GNP were revised upward aluing some contractions and downward during others. Five contractions were found to be more severe than previously estimated, athough in no case was the revision dramatic. The largest downward revision in real growth was for the $1948-49$ recession.

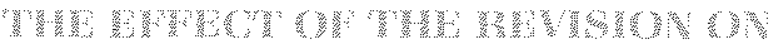

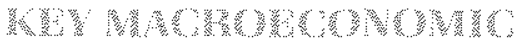

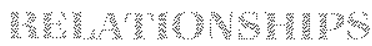

One question of interest to economists is whether the revision influenced certain key macroeconomic relationships that are used in analyzing the economy and formulating economic policy. While many rela* tionships could be examined, this section focuses specifically on four of them." Simple summary relationships were estimated for the 1956-84 period using

${ }^{3}$ For a summary and discussion of such relationships for the 1956-81 period, see Carlson and Hein (1983). 


\section{Table 4}

Real GNP Growth over the Business Cycle: Old and Revised Series (compounded annual rates of change)

\begin{tabular}{|c|c|c|c|c|c|c|c|}
\hline Expanslon & Prevous & Revisea & Change & Contracton & Provious & Revised & Change \\
\hline $11 / 949-11 / 953$ & $73 \%$ & $80 \%$ & 107 & $1 W / 948$ W/ 949 & $1,4 \%$ & $20 \%$ & 0.6 \\
\hline $111954-1111957$ & 3,9 & 34 & 105 & $1 / 1953$ 1/1954 & 32 & 30 & 102 \\
\hline $11958-1,1960$ & 55 & 5,4 & 00 & $1111957-11958$ & 66 & 10 & 0,4 \\
\hline $141960111 / 969$ & 47 & 45 & 02 & $1 / 960 \Omega / 1960$ & +15 & 134 & 101 \\
\hline $111970 \_$W1973 & $\$ 3$ & 46 & 01 & $111 / 969,1 / 1970$ & 00 & 07 & 102 \\
\hline $11975-11980$ & 44 & 41 & 03 & $1 \mathrm{N1973}, 11975$ & 39 & 35 & 104 \\
\hline $111980+111980$ & 33 & 27 & 10 & $1 / 1980,1 / 1909$ & 90 & $\$$ & 01 \\
\hline 114962 , 11998 & 46 & 18 & +ి & 11408, , 11,962 & 30 & +34 & $\$ 0,4$ \\
\hline
\end{tabular}

percentage changes where applicable on a fourthquarter-to-fourth-quarter basis. No attempt was made to search for the "best" equation; wathes, the equations were chosen for their illustrative simplicity. They are intended solely to illustrate the effect of the revision on the various relationships in the simplest form possible.

\section{W}

The relationship between money and GNP is a fun damental one in terms of the monetarist view of how total spending is determined. In a simple version, il can be estimated as the relationship between the fourquarter percent change of nominal GNP $\left(\bar{Y}_{4}\right)$ and the four-quarter percent change of money $\left(\dot{\mathrm{M}}_{*}\right)$. The equation used here also includes a dummy variable (D) for the 1982-84 period because previous studies have indicated that the relationship shifted significantly after 1981.

When this equation was estimated over the $1956-84$ period, using both the previously published and revised data, the results were those shown in lines la and $1 b$ of table 5 . An inspection of the estimated equations indicates a sligh strengthening in the relationship between nomina GNP and money, with the coeffcient on money staying chose to its theotetically expected value of one. The t-statistics (measures of the precision of the coefficient estimates increased; $\mathrm{K}^{2}$, a measure of the explanatory power of the equation, also rose. The standard emor (SE) of the equation, a

'For estimation purposes, only fourth-quarter data were used from each calendar year.

sWith the exception of the unemployment-real GNP equation, results presented here include this dummy variable. measure of the accuracy of the fitted equation in terms of its dependent variable, was reduced by 4 percent. The Dubin-Watson (DW) statistic, a measure of residual correlation, showed a slight improvement.

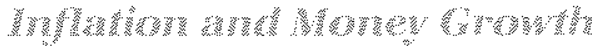

The relationship between inflation and money growth is another fundamental one in macroecononics. Since, during the 1970 s and 1980 s, changes in the price of energy played a key role affecting movements of the price level, this variable was also included in the estimation of the relationship. The estimated equation for inflation $\left(\dot{p}_{4}\right)$ includes the 16 -quates ate of change of money $\left(\dot{M}_{16}\right)$ measured from fourth quartes fo fouth quarter, the four-quarter percent change of the rela tive price of energy $(\dot{p}, \dot{s}$, and the dummy variable discussed earler.;

When estimated over the $1956-84$ period, the results were those shown in lines $2 a$ and $2 b$ of table 5 . As the statistics show, the revision improved the inflation equation marginaly; both $\overline{\boldsymbol{P}}^{2}$ and the standand eror improved sligthly, and the coefficient on money stayed close to ils expected value of one. In addition, the -statistics all increased. Signs of positive antocorrelation also appeared to be removed.

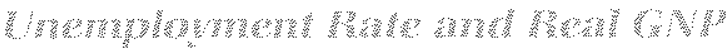

Another relationship of interest to macroeconomists is the relationship between the unemployment rate and the growth of real GNP, a variant of what is called Okun's law. In the simple relationship esti-

The choice of 16 quarters for money growth reflects previous research. See Carlson and Hein. 
Table 5

\section{Macroeconomic Relationships Using Old and Revised Data}

Money and Nominal GNP

(1 a) Using previously published data

$\mathrm{Y}_{4}=3,83+89 \mathrm{M}_{4}-3,51 \mathrm{D}$

$(4.10)(5.10)$ (2.35)

(1b) Usng revised dala

$\mathrm{Y}_{1}, 380+91 \mathrm{M}_{4}, 3,7 \mathrm{D}$

(4.26) $(5.43)$

(264)

Inflation and Money Growth

(2a) Using previously published data: $\mathrm{P}_{4}=08+97 \mathrm{~N}_{\mathrm{t}}+, 08 \mathrm{PE}+305 \mathrm{D}$

$(14)(66)$ ( $(306)$

$(3.46)$

$\overline{\mathrm{A}} \mathrm{\beta} \mathbf{8 2}$

$\mathrm{SE}=\mathrm{I} 15$

DW $\approx 1,65$

(2b) 4 sing revised dala:

$P_{4}=21{ }_{100} \mathrm{M}_{6}, 07 \mathrm{P}^{\mathrm{E}}, 310 \mathrm{D}$

(39) 1831

(3.14)

(3.67)

$\bar{B}^{2} \quad=84$

$\mathrm{SE}=110$

DW $=189$

Unemployment Rate and Real GNP

(3a) Using previously published data.

$\Delta U_{4}=120-34 X_{4}$

(7.36) $(8,15)$

(3b) Using revised data:

$\Delta U_{4}=15-35 \mathrm{X}_{4}$

$(7.34)(8.11)$

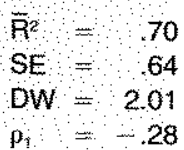

$\overline{\mathrm{A}}^{2}=70$

$\mathrm{SE}=67$

$\mathrm{DW}=199$

$p_{1}=-37$

Short-Term Interest Rate and Inflation

(4a) Using previously published data:

$R S=240+.91 P_{4}+1.22 D$
$(2.07)(5.67) \quad(92)$

(4b) Using revised data.

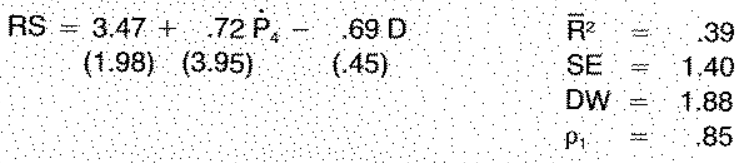

NOTE Absolute value of tstatistics in parentheses mated below, $\Delta U_{4}$ is the change in the unemployment rate from fourth quarter to fourth quarter, and $\dot{X}_{4}$ is the percent change in real GNP from fourth quarter to fourth quarter:

When this relationship was estimated from 1956 to 1984, the results were those shown in lines $3 a$ and $3 b$ of table 5. Because the residuals were negatively correlated, the equations were adjusted for first-order serial correlation. The estimates indicate that the explanam tory power of the relationship was unchanged using the revised data and that a 1 percent increase in output still reduces the unemployment mate by about one-third of a percentage point. The standard error increased only slightly, and the estimated coefficients did not change significantly.

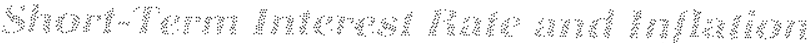

Interest ates generally move with the expected rate of inflation. Because expected inflation cannot be observed directly estimates of its effect on interest rates require the use of "proxies"; the actual rate of change in the GNP dellator is used here as an approximation for the expected rate in the interest rate equation. The four month commercial paper rate (RS) was estimated as a function of the four ${ }^{-}$quarter rate of inflation $\left(\dot{\boldsymbol{P}}_{1}\right)$ measured from fourth quarter to fourth quarter and the dummy variable described previously. "It was necessary to estimate the equation using a first-order serial correlation adjustment.

Lines $4 \mathrm{a}$ and $4 \mathrm{~b}$ of table 5 show the results. The shot-term interest rate relationship deteriorated when estimated with the revised data. Such a result is probably not surprising, since the revised data are different than those that were used by market participants to form expectations. Fven though the coefficient on inflation declined, it is not significantly different from one, its theoretically expected vatue.

\section{m:}

The Department of Commerce has recently revised the GNP accounts. The revision results from a variety of changes, including a shift of the base period from 1972 to 1982 . This change in base period affects constant-dollar, or real, estimates as well as serving as the base year for the price indexes.

${ }^{7} \mathrm{~A}$ similar attempt was made to estimate a long-term interest rate equation but the results were meaningless. Conventional adjustments were unsuccessful in removing the positive corretation of the residuals. 
The revision testled in substantial incases in the level of nominal GNP from 1948 to 1984. It had little effect on the rates of change of GNP. The revised figures for real GNP yield a slower pace of economic: growth; it was revised downward from a 3.4 pereent annual ate to a 3.2 percent rate from 1948 to 1985 . The rate of change of the GNP detlator was revised upward, from a 4.1 percent rate to a 4.3 percent rate over the period.

While the revision had no effect on business-cycle taming points, it had some impact on the strength of expansions and the severity of recessions. Revisions of the growth of real GNP over the business cycle were within the -0.7 to +0.7 pescentage-point lange.

This article also examined the effects of the revision on simple versions of certain key macroeconomic relationships. These relationships cover the impact of money growth on nominal GNP and inflation, the relationship between real GNP growth and unemployment, and the impact of inflation on short-term interest rates.

The results were mixed. The two relationships link. ing money growth to GNP and inflation improved marginally using the revised data. The other relationships deteriorated marginally on net, the reviston had no major effect on the pattern of recent fluctuations in the economy.

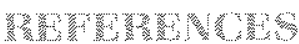

Carison, Keith M., and Scoit E. Hein. "Four Econometric Models and Monetary Policy: The Longer-Run View, "this Review (January 1983$)$, pp. 13-24.

Carson, Carol S. "The Underground Economy: An Introduction," Survey of Current Business (May 1984), pp. 21-37.

Parker, Robert $P$. "Improved Adjustments for Misreporting of Tax Return Information Used to Estimate the National income and Product Accounts, 1977," Survey of Current Business (June 1984), pp. $\$ 7-25$.

U.S. Department of Commerce, Bureau of Economic Analysis. "Simon Kuznets and the Early Development of National Income and Product Estimates," Survey of Current Business (July 1985a), pp. 27-28.

"An Advance Overview of the Comprehensive Revision of the National Income and Product Accounts," Survey of Current Business (October 1985b), pp. 19-28.

. "Revised Estimates of the National mcome and Product Accounts of the United States, 1929-85: An Introduction, Survey of Current Business (December 1985c), pp. 1 - 19 . 